\title{
Hubungan Persepsi Mahasiswa tentang Mata Kuliah Kewirausahaan dan Hasil Belajar dengan Minat Berwirausaha Mahasiswa Reguler Angkatan 2013 Pendidikan Ekonomi
}

\author{
Rosmiati $^{1}$ dan Zuhri Saputra Hutabarat ${ }^{2}$ \\ ${ }^{1}$ Dosen Universitas Jambi \\ ${ }^{2}$ Dosen Universitas Batanghari \\ Correspondence Email: rosmiati.fkip@unja.ac.id
}

\begin{abstract}
Abstrak: Setiap mahasiswa mempunyai perhatian khusus terhadap mata kuliah tertentu, hal tersebut dapat dilihat dari semangat dan minat belajar mahasiswa terhadap mata kuliah yang diminati oleh mahasiswa. Ada beberapa program mata kuliah yang diberikan kepada mahasiswa untuk membekali lulusan pendidikan ekonomi agar menjadi mandiri atau dapat berusaha sendiri. Tujuan dari penelitian yang dilakukan adalah mengetahui hubungan persepsi mahasiswa tentang mata kuliah kewirausahaan dan hasil belajar dengan minat berwirausaha mahasiswa reguler angkatan 2013 pendidikan ekonomi. Jenis penelitian ini adalah Korelasional. Subjek dalam penelitian ini adalah mahasiswa reguler angkatan 2013 Pendidikan Ekonomi sebanyak 44 orang. Data diperoleh dengan menyebarkan angket. Setelah itu dianalisis dengan korelasi parsial product moment dan korelasi ganda. Hasil penelitian ini menunjukkan bahwa persepsi mahasiswa tentang mata kuliah kewirausahaan berkriteria baik terhadap hasil belajar mahasiswa, serta memiliki minat berwirausaha yang tinggi. Penelitian ini juga menunjukkan hubungan yang tinggi dan signifikan antara antara persepsi mahasiswa tentang mata kuliah kewirausahaan dengan minat berwirausaha pada mahasiswa reguler angkatan 2013 pendidikan ekonomi ,yaitu sebesar r hitung 0,694. Terdapat hubungan signifikan antara hasil belajar dengan minat berwirausaha pada mahasiswa reguler angkatan 2013 pendidikan ekonomi, yaitu sebesar $\mathrm{r}_{\text {hitung }} 0,703$. Terdapat hubungan yang signifikan antara persepsi mahasiswa tentang mata kuliah kewirausahaan dan hasil belajar dengan minat berwirausaha pada mahasiswa reguler angjatan 2013 pendidikan ekonomi ,yaitu sebesar rhitung 0,740 .
\end{abstract}

Kata Kunci: Persepsi Mahasiswa dan Hasil Belajar dengan Minat Berwirausaha

\begin{abstract}
Each student has special attention to certain courses, it can be seen from the enthusiasm and interest in student learning towards the subjects that are interested by the students. There are several subjects' programs that are given to students to equip economic education graduates to become independent or to be able to work on themselves. The purpose of the research was to know the relationship between student perceptions of entrepreneurship courses and learning outcomes with the interest in entrepreneurship of regular students in the 2013 of economic education. This design of research is correlational. The subjects of this research were regular students of the 2013 Economics Education, they were 44 students. Data was obtained by distributing questionnaires. After that, it was analyzed by partial product moment correlation and multiple correlation. The results of this research were indicated that students' perceptions of entrepreneurship courses have good criteria for student learning outcomes, and have a high interest in entrepreneurship. This research also shows a high and significant relationship between students' perceptions of entrepreneurship courses and interest in entrepreneurship in regular students of 2013 economic education, which was equal to recount 0.694. There is a significant relationship between learning outcomes and interest in entrepreneurship in the 2013 economic education regular students, which is equal to recount 0.703. There is a significant relationship between students' perceptions of entrepreneurship courses and learning outcomes with interest in entrepreneurship in regular students of 2013 class of economics education, which is equal to recount 0.740 .
\end{abstract}

Keywords: Student Perceptions, Learning Outcomes and Entrepreneurial Interest

\section{PENDAHULUAN}

Tujuan pendidikan nasional berdasarkan UU RI NO. 20 tahun 2003 tentang Sistem Pendidikan Nasional, sebagai berikut: Pendidikan nasional bertujuan untuk berkembangnya potensi peserta didik agar menjadi manusia yang beriman dan bertaqwa kepada Tuhan YME, berakhlak mulia, sehat, berilmu, cakap, kreatif, mandiri dan menjadi warga Negara yang demokratis serta bertanggung jawab. Tujuan pendidikan yang hendak dicapai pemerintah Indonesia adalah mencerdaskan kehidupan bangsa. Oleh karena itu pemerintah telah memberikan kesempatan yang luas untuk memperoleh pendidikan bagi seluruh Rakyat Indonesia. Dalam tugasnya sehari-hari guru dihadapkan pada suatu permasalahan yaitu ia harus memberi pengajaran yang sama kepada murid yang berbeda-beda. Perbedaan itu berasal dari lingkungan kebudayaan, 
Rosmiati dan Zuhri Saputra Hutabarat, Hubungan Persepsi Mahasiswa tentang Mata Kuliah Kewirausahaan dan Hasil Belajar dengan Minat Berwirausaha Mahasiswa Reguler Angkatan 2013 Pendidikan Ekonomi

lingkungan sosial, jenis kelamin dan lain-lain. Setiap mahasiswa mempunyai perhatian khusus terhadap mata kuliah tertentu, hal tersebut dapat dilihat dari semangat dan minat belajar mahasiswa terhadap mata kuliah yang diminati oleh mahasiswa. Ada beberapa program mata kuliah yang diberikan kepada mahasiswa untuk membekali lulusan pendidikan ekonomi agar menjadi mandiri atau dapat berusaha sendiri. Salah satunya dari program matakuliah tersebut adalah kewirausahaan. mata kuliah kewirausahaan ini jika diberikan dengan tehnik yang baik dan tidak semata-mata hanya mentrasfer ilmu pengetahuan saja, dosen terampil dalam memberikan motivasi kepada mahasiswa maka program mata kuliah ini akan menggugah minat mahasiswa dalam mengembangkan jiwakewirausahaanya. Mahasiswa akan terdorong minatnya untuk menekuni materi kewirausahaan dan terbuka dirinya untuk memperoleh rangsangan-rangsangan untuk mempunyai jiwa kewirausahaan.

Berdasarkan dari uraian diatas,maka peneliti merasa tertarik untuk melakukan penelitian yang berjudul "Hubungan Persepsi Mahasiswa Tentang Mata Kuliah Kewirausahaan dan Hasil Belajar dengan Minat Berwirausaha Mahasiswa Reguler Angkatan 2013 Pendidikan Ekonomi ”

\section{LANDASAN TEORI}

Menurut Agus Bastian dalam Agus Wibowo (2011:27), kewirausahaan bisa dihasilkan dari learning by doing, juga dari semangat mengambil resiko tanpa takut, bukan lewat pendidikan khusus kewirausahaan atau manajemen. Modal utama seorang wirausahawan itu bukanlah uang melainkan kreativitas, tanpa kreativitas seseorang tidak akan menjadi wirausahawan sejati, tetapi hanya pedagang biasa. Jika kita cermati, setiap tahun PTN maupun PTS meluluskan sarjananya. Sayangnya, para sarjana itu tidak semuanya bisa diserap dunia usaha atau pasar kerja. Memang banyak faktor yang melatarbelakanginya; seperti jumlah lapangan kerja yang tidak sebanding dengan jumlah lulusan, budaya dan mental sarjana yang hanya mengejar pekerjaan kantoran sehingga mengesampingkan lapangan kerja dan sebagainya. Kewirausahaan merupakan kegiatan yang menuntut karakteristik tertentu dari pelakunya dan kegitan untuk melakukan usaha tersebut. Oleh karena itu, Clelland yang dikutip Suryana dalam Mustofa Kamil (2012:122) bahwa karakteristik wirausaha adalah :

1. Keterampilan mengambil keputusan dan mengambil risiko yang moderat, dan bukan atas dasar kebutuhan belaka.

2. Bersifat energetik, khususnya dalam bentuk berbagai kegiatan inovatif.

3. Tanggung jawab individual.

4. Mengetahui hasil-hasil dari berbagai keputusan yang diambilnya dengan tolok ukur satuan uang sebagai indikator keberhasilan.

5. Mampu mengantisipasi berbagai kemungkinan dimasa datang.

6. Memiliki kemampuan berorganisasi, yaitu seseorang wirausaha memiliki kemampuan keterampilan, kepemimpinan, dan manajerial.

Minat berwirausaha adalah kecenderungan hati yang besar terhadap sesuatu yang disenangi, perasaan tertarik ,kepercayaan, pemusatan yang tidak disengaja terlahir dengan penuh kemauan sehingga timbul lah rasa keingin tahuan terhadap hal tersebut dan ingin mencoba. persepsi mahasiswa tentang mata kuliah kewirausahaan yaitu agar pendidikan kewirausahaan di kampus bisa optimal, maka pembentukan budaya, mental dan perilaku kewirausahaan tidak hanya terhadap dosen atau staf pengajar lainnya, tetapi juga terhadap mahasiswa berdasarkan pengalaman, minat, pengetahuan dan penerimaan.

Bimo Walgito (2010:99) Persepsi merupakan suatu proses yang didahului oleh penginderaan, yaitu merupakan proses diterimanya stimulus oleh individu melalui alat indera atau juga disebut proses sensoris. Namun proses itu tidak berhenti begitu saja, melainkan stimulus tersebut diteruskan dan proses selanjutnya merupakan proses persepsi. Selain itu, Jalaluddin Rachmat (2000:56) juga mengungkapkan bahwa persepsi adalah proses penginderaan,pemahaman, penafsiran dan penyimpulan.

Menurut Moskowitz dan orgel dalam Bimo Walgito (2010:100) persepsi merupakan proses yang integrated dalam diri individu terhadap stimulus yang diterimanya, Sedangkan menurut Slameto (2013:102) 
Rosmiati dan Zuhri Saputra Hutabarat, Hubungan Persepsi Mahasiswa tentang Mata Kuliah Kewirausahaan dan Hasil Belajar dengan Minat Berwirausaha Mahasiswa Reguler Angkatan 2013 Pendidikan Ekonomi

persepsi adalah proses yang menyangkut masuknya pesan atau informasi ke dalam otak manusia. Melalui persepsi manusia terus-menerus mengadakan hubungan dengan lingkungannya. Hubungan ini dilakukan lewat inderanya, yaitu indera penglihatan, pendengar, peraba, perasa, pencium. Mengetahui dan menerapkan prinsip-prinsip yang berhubungan dengan persepsi mahasiswa sangat penting karena makin baik suatu objek, orang, peristiwa atau hubungan diketahui, makin baik pula hal tersebut dapat diingat.

Hasil Belajar adalah kemampuan yang diperoleh siswa setelah melalui kegiatan belajar. Karena belajar itu sendiri merupakan suatu proses dari seseorang yang berusaha untuk memperoleh suatu bentuk perubahan perilaku yang relatif menetap. Sedangkan Hasil Belajar menurut Bloom dalam Harun Rasyid dan Mansur (2007:13) mencakup peringkat dan tipe prestasi belajar, kecepatan belajar, dan hasil efektif. Menurut Harun Rasyid dan Mansur (2007:6) Penilaian merupakan komponen penting dalam penyelenggaraan pendidikan. Upaya meningkatkan kualitas pendidikan dapat ditempuh melalui peningkatan kualitas pembelajaran dan kualitas sistem penilaiannya. Keduanya saling terkait, sistem pembelajaran yang baik akan menghasilkan kualitas belajar yang baik. Kualitas pembelajaran ini dapat dilihat dari hasil penilaiannya.

Kelleough dalam Harun Rasyid dan Mansur (2007:7) mengidentifikasi tujuan penilaian adalah untuk : (1) membantu belajar siswa, (2) mengidentifikasi kekuatan dan kelemahan siswa, (3) menilai efektifitas strategi pengajaran, (4) menilai dan meningkatkan efektifitas program kurikulum, (5) menilai dan meningkatkan efektivitas pengajaran, (7) komunikasi dan melibatkan orang tua siswa.

Tujuan penilaian diatas memberi gambaran bahwa penilaian memegang peranan yang sangat penting dalam upaya meningkatkan kualitas pembelajaran. Oleh karena itu, memilih metode penilaian yang tepat untuk digunakan dalam suatu proses pembelajaran perlu pemikiran dan pertimbangan yang matang bagi seorang guru. Hal-hal yang perlu diperhatikan misalnya kesesuaian dengan muatan materi pembelajaran, waktu, praktis,dapat dilaksanakan, dan memberikan informasi yang sesuai untuk digunakan dalam meningkatkan kualitas belajar siswa.

\section{METODE PENELITIAN}

Penelitian ini adalah penelitian korelasional, yang menghubungkan antara dua variabel atau lebih. Menurut Sukardi (2003:166) penelitian korelasional adalah suatu penelitian yang melibatkan tindakan pengumpulan data guna menentukan, apakah ada hubungan dan tingkat hubungan antara dua variabel atau lebih. Besarnya hubungan tersebut dinyatakan dalam bentuk koefisien korelasi,

Populasi yang dijadikan dalam penelitian ini adalah berjumlah 44 orang, sehingga keseluruhan populasi dijadikan sampel dalam penelitian ini. Sampel penelitian adalah sebagian dari populasi yang diambil sebagai sumber data dapat mewakili seluruh populasi. Adapun jumlah populasi dalam penelitian ini adalah 44 orang. Sesuai pendapat Arikunto (2006:125) menyatakan bahwa jika jumlah anggota subjek dalam populasi dibawah 150 orang dan dalam pengumpulan data peneliti menggunakan angket sebaiknya subjek diambil seluruhnya. Jadi, jenis penelitian ini termasuk penelitian sensus yaitu mengambil sampel penelitian secara keseluruhan yang berjumlah 44 responden. Teknik yang digunakan dalam penelitian ini adalah Probability Sampling. Probability Sampling adalah teknik pengambilan sampel yang memberikan peluang yang sama bagi setiap unsur (anggota) populasi untuk dipilih menjadi anggota sampling (Sugiyono, (2013:118). Pengumpulan data dapat dilakukan dengan angket, angket yang dilakukan adalah untuk mengetahui ada tidaknya hubungan persepsi mahasiswa tentang mata kuliah kewirausahaan dan hasil belajar dengan minat berwirausaha mahasiswa reguler angkatan 2013 Pendidikan ekonomi. Angket ini dilakukan dengan penyebaran dan penarikan instrumen. Untuk menjawab rumusan masalah yang pertama dan kedua yaitu mengenai hubungan antara persepsi mahasiswa tentang mata kuliah kewirausahaan dengan minat 
Rosmiati dan Zuhri Saputra Hutabarat, Hubungan Persepsi Mahasiswa tentang Mata Kuliah Kewirausahaan dan Hasil Belajar dengan Minat Berwirausaha Mahasiswa Reguler Angkatan 2013 Pendidikan Ekonomi

berwirausaha mahasiswa reguler angkatan 2013 pendidikan ekonomi dan hubungan antara hasil belajar dengan minat berwirausaha mahasiswa reguler angkatan 2013 pendidikan ekonomi dengan menggunakan rumus korelasi sederhana product moment yaitu:

$$
r_{x y}=\frac{\mathrm{n} \sum \mathrm{X}_{\mathrm{i}} \mathrm{Y}_{\mathrm{i}}-\left(\sum \mathrm{X}_{\mathrm{i}}\right)\left(\sum \mathrm{Y}_{\mathrm{i}}\right)}{\sqrt{\left.\mathrm{n} \sum \mathrm{Xl}^{2}-\left(\sum \mathrm{Xl}^{2}\right)\right\}\left\{\mathrm{n} \sum \mathrm{Yl}^{2}-\left(\sum \mathrm{Yl}^{2}\right)^{2}\right.}}
$$

Keterangan:

$r_{x y}=$ Koefisien korelasi

$\mathrm{n} \quad=$ Jumlah sampel

$\mathrm{x}_{\mathrm{i}}=$ Skor butir

$\mathrm{Y}_{\mathrm{i}}=$ Skor total

$\mathrm{Y} \quad=$ Nilai variabel $\mathrm{Y}$

$\mathrm{n} \quad=$ Jumlah angket

(Riduwan, 2012:138)

Untuk mengetahui signifikan koefisien korelasi dihitung dengan menggunakan uji t yang rumusnya sebagai berikut:

$t=\frac{r \sqrt{n-2}}{\sqrt{1-r^{2}}}$

(Sugiyono, 2012:184)

Dimana:

$\mathrm{t} \quad=$ Nilai uji $\mathrm{t}$

$\mathrm{r} \quad=$ Koefisien korelasi

$\mathrm{n} \quad=$ Jumlah sampel

Dengan ketentuan bila $t_{\text {hitung }}>t_{\text {tabel }}$ maka korelasi antara kedua variabel tersebut signifikan $\sigma 0,05$ uji dua pihak dan $\mathrm{dk}=\mathrm{n}-2$. Untuk memberi interpretasi terhadap kuatnya hubungan antar variabel yang diteliti, maka dapat digunakan tabel interpretasi (Riduwan 2012:138) sebagai berikut:

\begin{tabular}{|c|c|}
\hline Interval Koefisien & Tingkat Hubungan \\
\hline $0,80-1,00$ & Sangat Tinggi \\
\hline $0,60-0,799$ & Tinggi \\
\hline $0,40-0,599$ & Cukup Tinggi \\
\hline $0,20-0,399$ & Rendah \\
\hline $0,00-0,199$ & Sangat rendah \\
\hline
\end{tabular}

Untuk menjawab rumusan masalah yang ketiga yaitu hubungan antara persepsi mahasiswa tentang mata kuliah kewirausahaan dan hasil belajar dengan minat berwirausaha mahasiswa reguler angkatan 2013 pendidikan ekonomi menggunakan korelasi ganda yaitu:

$$
R x_{1} \cdot x_{2} \cdot y=\sqrt{\frac{r^{2} x_{1} \cdot y+r^{2} x_{2} \cdot y-2\left(r x_{1} \cdot y\right) \cdot\left(r x_{2} \cdot y\right) \cdot\left(r x_{1} \cdot x_{2}\right)}{1-r^{2} x_{1} \cdot x_{2}}}
$$

Keterangan:

$R_{Y x_{1} x_{2}}=$ Korelasi antara variabel $X_{1}$ dan $X_{2}$ secara bersama-sama dengan variabel Y

$r_{y x_{1}}=$ Korelasi Products Moment antara $X_{1}$ dan Y

$r_{y x_{2}}=$ Korelasi Products Moment antara $X_{2}$ dan Y

$r_{x_{1} x_{2}}=$ Korelasi Products Moment antara $X_{1} \operatorname{dan} X_{2}$ 
Rosmiati dan Zuhri Saputra Hutabarat, Hubungan Persepsi Mahasiswa tentang Mata Kuliah Kewirausahaan dan Hasil Belajar dengan Minat Berwirausaha Mahasiswa Reguler Angkatan 2013 Pendidikan Ekonomi

Menurut (Sugiyono (2012:235), selanjutnya untuk mengetahui signifikan korelasi ganda, digunakan rumus:

$F_{\text {hitung }}=\frac{R^{2} / k}{\left(1-R^{2}\right) /(n-k-1)}$

Keterangan:

$\mathrm{R} \quad=$ Koefisien korelasi ganda

$\mathrm{k}=$ Jumlah variabel bebas (independen)

$\mathrm{n} \quad=$ Jumlah anggota sampel

$F_{\text {hitung }} \quad=$ Nilai $\mathrm{F}$ yang dihitung

Jika $F_{\text {hitung }} \geq F_{\text {tabel, }}$ maka Ho ditolak yang artinya signifikan dan jika $F_{\text {hitung }} \leq \mathrm{Ft}_{\text {abel }}$ Ho diterima yang artinya tidak signifikan.

\section{HASIL PENELITIAN DAN PEMBAHASAN}

1. Berdasarkan hasil perhitungan uji normalitas tersebut dapat diketahui bahwa data persepsi mahasiswa tentang mata kuliah kewirausahaan dengan rata-rata skor angket sebesar 78,93 dan SD sebesar 7,48 dengan membandingkan $X^{2}$ hitung dengan nilai $X^{2}$ tabel untuk $a=0,05$ derajat kebebasan $(\mathrm{dk})=\mathrm{k}-2=$ 6- $2=4$, maka dicari pada tabel chi-kuadrat didapat $X^{2}$ tabel $=9,888$. Ternyata Jika $X^{2}$ hitung $\leq X^{2}$ tabel, atau $-103,62 \leq 9,888$, maka data persepsi mahasiswa tentang mata kuliah kewirausahaan adalah berdistribusi Normal.

2. Berdasarkan hasil perhitungan uji normalitas tersebut dapat diketahui bahwa data Hasil belajar dengan rata-rata skor hasil belajart sebesar 75,86 dan SD sebesar 4,089 dengan membandingkan $X^{2}$ hitung dengan nilai $X^{2}$ tabel untuk $a=0,05$ derajat kebebasan $(\mathrm{dk})=\mathrm{k}-2=6-2=4$, maka dicari pada tabel chi-kuadrat didapat $\mathrm{X}^{2}$ tabel $=9.888$ Ternyata Jika $\mathrm{X}^{2}$ hitung $\leq \mathrm{X}^{2}$ tabel atau 3,153 $\leq 9,888$, maka data Hasil belajar adalah berdistribusi Normal.

3. Berdasarkan hasil perhitungan uji normalitas tersebut dapat diketahui bahwa data Minat berwirausaha dengan rata-rata skor angket sebesar 94,81 dan SD sebesar 10,37 dengan membandingkan $\mathrm{X}^{2}$ hitung dengan nilai $X^{2}$ tabel untuk $a=0,05$ derajat kebebasan $(\mathrm{dk})=\mathrm{k}-2=6-2=4$, maka dicari pada tabel chi-kuadrat didapat $\mathrm{X}^{2}$ tabel $=9.888$. Ternyata Jika $\mathrm{X}^{2}$ hitung $\leq \mathrm{X}^{2}$ tabel, atau $-126,85 \leq 9.888$, maka data minat berwirausaha adalah berdistribusi Normal.

Berdasarkan hasil perhitungan homogenitas antara $\mathrm{X}_{1}$ dan $\mathrm{Y}$ dengan membandingkan Fhitung dengan Ftabel untuk $\mathrm{a}=0,05$ diperoleh Fhitung $=0,520$ dengan $\mathrm{dk}$ pembilang $=44-1=43$. maka dicari pada tabel $\mathrm{F}$ didapat Ftabel $=1,66$. Ternyata Fhitung $\leq$ Ftabel, atau $0,520 \leq \leq 1,66$, maka variabel adalah homogen.

2. Berdasarkan hasil perhitungan homogenitas antara $X_{2}$ dan $Y$ dengan membandingkan Fhitung dengan Ftabel untuk $a=0,05$ diperoleh Fhitung $=0,573$ dengan $\mathrm{dk}$ pembilang $=44-1=43$. Maka dicari pada tabel $\mathrm{F}$ didapat Ftabel $=1,66$ Ternyata Fhitung $\leq$ Ftabel, atau $0,573 \leq 1,66$, maka variabel adalah homogen.

Dari hasil analisis perhitungan hubungan persepsi mahasiswa tentang mata kuliah kewirausahaan $\left(\mathrm{X}_{1}\right)$ dengan minat berwirausaha $(\mathrm{Y})$ pada mahasiswa reguler agkatan 2013 pendidikan ekonomi diperoleh $\mathrm{rx}_{1 \mathrm{y}}$ sebesar 0,694. Bila dibandingkan dengan $\mathrm{r}$ tabel sebesar 0,297, maka nilai $\mathrm{r}$ hitung $\geq \mathrm{r}$ tabel atau 0,694 $\geq$ 0,297. Hasil ini kemudian dikonsultasikan ke dala tabel interpretasi koefisien korelasi. Berdasarkan tabel interpretasi koefisien korelasi, data tersebut menjelaskan bahwa terdapat hubungan yang tinggi antara persepsi mahasiswa tentang mta kuliah kewirausahaan dengan minat berwirausaha.

Dari hasil analisis perhitungan antara hubungan hasil belajar $\left(\mathrm{X}_{2}\right)$ dengan minat berwirausaha $(\mathrm{Y})$ pada mahasiswa reguler angkatan 2013 pendidikan ekonomi diperoleh $\mathrm{rx}_{2 \mathrm{y}}$ sebesar 0,703. Bila dibandingkan dengan $r$ tabel sebesar 0,297, maka nilai $r$ hitung $\geq \mathrm{r}$ tabel atau 0,0,703 $\geq 0,297$. Hasil ini kemudian 
Rosmiati dan Zuhri Saputra Hutabarat, Hubungan Persepsi Mahasiswa tentang Mata Kuliah Kewirausahaan dan Hasil Belajar dengan Minat Berwirausaha Mahasiswa Reguler Angkatan 2013 Pendidikan Ekonomi

dikonsultasikan ke data tabel interpretasi koefisien korelasi. Berdasarkan tabel interpretasi koefisien korelasi, data tersebut menjelaskan bahwa terdapat hubungan yang tinggi antara hasil belajar dengan minat berwirausaha.

Hubungan persepsi mahasiswa tentang mata kuliah kewirausahaan dan hasil belajar dengan minat berwirausaha mahasiswa reguler angkatan 2013 pendidikan ekonomi, dalam penelitian ini terdapat tiga (3) rumusan masalah yaitu : (1) Apakah terdapat hubungan persepsi mahasiswa tentang mata kuliah kewirausahaan dengan minat berwirausaha mahasiswa reguler angkatan 2013 pendidikan ekonomi; (2) Apakah terdapat hubungan hasil belajar dengan minat berwirausaha mahasiswa reguler angkatan 2013 pendidikan ekonomi; dan (3) Apakah terdapat hubungan persepsi mahasiswa tentang mata kuliah kewirausahaan dan hasil belajar dengan minat berwirausaha mahasiswa reguler angkatan 2013 pendidikan ekonomi.

Dalam rumusan masalah pertama yaitu, Apakah terdapat hubungan persepsi mahasiswa tentang mata kuliah kewirausahaan dengan minat berwirausaha mahasiswa reguler angkatan 2013 pendidikan ekonomi, berdasarkan analisis dengan menggunakan korelasi parsial diperoleh $r$ hitung 0,694 nilai $r$ tabel 0,297 nilai tersebut menunjukkan adanya hubungan/korelasi yang signifikan antara persepsi mahasiswa tentang mata kuliah kewirausahaan dan hasil belajar dengan minat berwirausaha mahasiswa reguler angkatan 2013 pendidikan ekonomi. Ini dikarenakan persepsi yang baik terhadap mata kuliah kewirausahaan yang bisa menimbulkan minat dalam berwirausaha. Menurut Moskowitz dan orgel dalam Bimo Walgito (2010:100) persepsi merupakan proses yang integrated dalam diri individu terhadap stimulus yang diterimanya, Sedangkan menurut Slameto (2013:102) persepsi adalah proses yang menyangkut masuknya pesan atau informasi ke dalam otak manusia. Melalui persepsi manusia terus-menerus mengadakan hubungan dengan lingkungannya. Hubungan ini dilakukan lewat inderanya, yaitu indera penglihatan, pendengar, peraba, perasa, pencium. Mengetahui dan menerapkan prinsip-prinsip yang berhubungan dengan persepsi mahasiswa sangat penting karena makin baik suatu objek, orang, peristiwa atau hubungan diketahui, makin baik pula hal tersebut dapat diingat.

Dalam rumusan masalah ke dua yaitu Apakah terdapat hubungan hasil belajar dengan minat berwirausaha mahasiswa reguler angkatan 2013 pendidikan ekonomi. Berdasarkan analisis korelasi parsial diperoleh rhitung sebesar 0,703 sedangkan nilai rtabel 0,297 nilai tersebut menunjukkan adanya hubungan/korelasi yang signifikan antara hasil belajar dengan minat berwirausaha mahasiswa reguler angkatan 2013 pendidikan ekonomi. Ini dikarenakan peranan hasil belajar hanya sebagian yang dapat meningkatkan minat dalam berwirausaha dan terdapat faktor-faktor lain yang dapat meningkatkan hasil belajar.

Dalam rumusan masalah ke tiga yaitu Apakah terdapat hubungan persepsi mahasiswa tentang mata kuliah kewirausahaan dan hasil belajar dengan minat berwirausaha mahasiswa reguler angkatan 2013 pendidikan ekonomi, berdasarkan analisis korelasi ganda diperoleh rhitung sebesar 0,766 sedangkan nilai rtabel 0,297 nilai tersebut menunjukkan adanya hubungan /korelasi antara persepsi mahasiswa tentang mata kuliah kewirausahaan dan hasil belajar dengan minat berwirausaha mahasiswa reguler angkatan 2013 pendidikan ekonomi. Dengan demikian dapat di simpulkan bahwa semakin baik persepsi mahasiswa tentang mata kuliah kewirausahaan dan hasil belajar maka semakin tinggi minat berwirausaha, begitu pula sebaliknya.

\section{SIMPULAN}

Berdasarkan hasil perhitungan dan pembahasan yang penulis lakukan tentang hubungan persepsi mahasiswa tentang mata kuliah kewirausahaan dan hasil belajar dengan minat berwirausaha mahasiswa reguler 2013 pendidikan ekonomi :

1. Terdapat hubungan yang signifikan antara persepsi mahasiswa tentang mata kuliah kewirausahaan dengan minat berwirausaha pada mahasiswa reguler angkatan 2013 pendidikan ekonomi, yaitu sebesar $\mathrm{r}_{\text {hitung }}$ 0,694. Dengan demikian dapat disimpulkan bahwa semakin baik persepsi mahasiswa tentang mata kuliah kewirausahaan, maka semakin tinggi minat berwirausaha mahasiswa. 
Rosmiati dan Zuhri Saputra Hutabarat, Hubungan Persepsi Mahasiswa tentang Mata Kuliah Kewirausahaan dan Hasil Belajar dengan Minat Berwirausaha Mahasiswa Reguler Angkatan 2013 Pendidikan Ekonomi

2. Terdapat hubungan signifikan antara hasil belajar dengan minat berwirausaha pada mahasiswa reguler angkatan 2013 pendidikan ekonomi, yaitu sebesar $r_{\text {hitung }}$ 0,703 .Jadi dapat dikatakan, semakin tinggi hasil belajar mahasiswa tentang mata kuliah kewirausahaan maka semakin tinggi minat berwirausaha mahasiswa.

3. Terdapat hubungan yang signifikan antara persepsi mahasiswa tentang mata kuliah kewirausahaan dan hasil belajar dengan minat berwirausaha pada mahasiswa reguler angjatan 2013 pendidikan ekonomi ,yaitu sebesar $r_{\text {hitung }} 0,740$.sehingga dapat dikatakan bahwa semakin baik persepsi mahasiswa tentang mata kuliah kewirausahaan dan hasil belajar maka akan semakin tinggi minat berwirausaha.

\section{DAFTAR PUSTAKA}

Arikunto, Suharsimi. 2006. Prosedur Penelitian Suatu Pendekatan Praktek. Jakarta : Rineka Cipta.

Arikunto, Suharsimi. 2010. Prosedur Penelitian Suatu Pendekatan Praktek. Jakarta : Rineka Cipta.

Dalyono, M. 2012. Psikologi Pendidikan. Jakarta : Rineka Cipta.

Dimyanti Dan Mudjiono. 2010. Belajar Dan Pembelajaran, Jakarta : Rineka Cipta

Jihad, Asep Dan Haris, A. 2012. Evaluasi Pembelajaran. Yogyakarta : Multi Pressindo.

Kamil, Mustofa. 2012. Model Pendidikan Dan Pelatihan. Bandung : Alfabeta.

Prawikusumo, Soeharto. 2010. Kewirausahaan dan Manajemen Usaha Kecil. Yogyakarta:BPFE Yogyakarta. Rasyid, Harun Dan Mansyur. 2007. Penilaian Hasil Belajar. Bandung : Wacana Prima.

Rachmat, Jalaluddin. 2000. Psikologi Komunikasi. Bandung : Rosda Karya

Riduwan. 2012. Belajar Mudah Penelitian Untuk Guru-Karyawan dan Peneliti Pemula. Bandung: Alfabeta.

Slameto. 2013. Belajar dan Faktor-Faktor Yang Mempengaruhinya. Jakarta: Rineka Cipta.

Sugiyono. 2010. Metode Penelitian Pendidikan Pendekatan Kuantitatif, Kualitatif, dan R\&D. Bandung: Alfabeta.

Sugiyono. 2012. Statistika Untuk Penelitian. Bandung : Alfabeta.

Sukardi. 2003. Metodologi Penelitian Pendidikan. Yogyakarta : Bumi Aksara.

Uno. B. Hamzah. 2014. Belajar Dan Pembelajaran, Jakarta : Bumi Aksara.

Walgito, Bimo. 2010. Psikologi Umum. Yogyakarta : Andi Offset.

Wibowo, Agus. 2011. Pendidikan Kewirausahaan (Konsep dan Strategi). Yogyakarta: Pustaka Pelajar. 